\title{
Clamo Ergo Sum: Establishing a Fundamental Right to Protest from Christian Theologies of Liberation
}

\author{
Marc V. Rugani (D)
}

check for updates

Citation: Rugani, Marc V. 2021. Clamo Ergo Sum: Establishing a Fundamental Right to Protest from Christian Theologies of Liberation. Humanities 10: 102. https://doi.org/ 10.3390/h10030102

Received: 1 June 2021

Accepted: 7 September 2021

Published: 13 September 2021

Publisher's Note: MDPI stays neutral with regard to jurisdictional claims in published maps and institutional affiliations.

Copyright: (C) 2021 by the author. Licensee MDPI, Basel, Switzerland. This article is an open access article distributed under the terms and conditions of the Creative Commons Attribution (CC BY) license (https:/ / creativecommons.org/licenses/by/ $4.0 /)$.
Theology Department, Saint Anselm College, Manchester, NH 03102, USA; mrugani@anselm.edu

\begin{abstract}
The prevailing particular historical narratives that established the modern rights system greatly affect the participation, tenor, and limits of rights discourse today, too often ignoring or suppressing voices of those suffering or silenced. This essay is a contribution to the subversion of those histories, adverting to inconsistencies, in particular histories of modern rights, the need to amplify the voices of those suffering on the margins of that history, and the dangerous consequences if we fail to do so. By applying Enrique Dussel's political philosophy and Gustavo Gutiérrez's theology of liberation significant contributions can be made toward affirming a fundamental right to protest. The right to protest articulates a right co-foundational with the rights to life, liberty, and property, and this right is well grounded in a Christian account of the dignity of the human person.
\end{abstract}

Keywords: protest; rights; Enrique Dussel; Gustavo Gutiérrez; modernity; liberation theology; dignity

\section{Introduction}

The modern rights regime did not develop in "History" but through the telling of particular histories. Those who claim otherwise-who argue singular modern accounts of universal history that provide a privileged, objective viewpoint "from above" from which one can view the succession of events in human "progress" or "decline" —are those who "have the say" (Walsh 1987). ${ }^{1}$ However, the irruption of new voices in protest in the 20th and 21st centuries should disquiet the consciences of those who make such presumptions. In the US, for example, books such as Howard Zinn's A People's History of the United States and Nikole Hannah-Jones's journalistic experiment "The 1619 Project," have drawn criticism, outrage, and outright dismissal for the very thought that histories are subjective and dynamic (Zinn 2003; Hannah-Jones 2019). Voices "from below" call for new histories and revisions of established narratives to include formerly silent/silenced voices in the discourse on human rights. The Peruvian theologian Gustavo Gutiérrez wrote:

Remaking ... history, redoing it, means that we have to 'subvert' it, turn it around and make it flow backward-make it flow not from above but from below. The established order has inculcated in us a pejorative concept of subversion: subversion is dangerous to the established order. But from the other viewpoint, the great wrong is to become-or, perhaps, to continue to be-a 'super-versive,' a bulwark and support of the prevailing domination, someone whose orientation of history begins with the great ones of this world. (Gutiérrez 1983, p. 202)

Most particular histories of the modern rights regime, as they have been told, greatly affect the participation, tenor, and limits of the rights discourse today, and too often, too little attention is paid to those who have suffered or have been silenced despite all talk of their rights. ${ }^{2}$ Inspired by Gutiérrez's call, I intend this essay to be a contribution to the subversion of the history of the modern rights system, which adverts to its inconsistencies, the need to amplify the voices of those suffering on the margins of that history, and a warning of consequences should we fail to do so. ${ }^{3}$

I argue here that one must affirm and defend the priority of the right to protest alongside, and even over, fundamental subjective rights such as the rights to life, liberty, 
and property. Though provocative, I want to directly challenge the Lockean canon of fundamental rights to show that without consideration of alternative sources and potential revisions to this triad, those very three important rights will be in greater jeopardy than if one merely defends the status quo. To focus my argument's scope, I intend a narrow definition of the verb "to protest": a speech act objecting to or opposing others' words and deeds. This present limitation does not want to deny the defensibility of other forms of protest, widely defined, which often accompany speech acts, such as physical performance, demonstration, and resistance, but these forms require greater detail and attention than possible in the scope of this essay. From the perspective of Dussel, rhetorical acts of language are the fundamental means to achieving consensus and building an authentic community. For Gutiérrez, the words of the divine Logos, Christ, not only repudiate injustice and oppression and express divine solidarity with those thus suffering, but they also prophesy of an unhoped-for future of authentic, just community in the Kingdom of God. The roots of the verb "to protest" in Middle English and Latin carry the connotation of a solemn declaration, making the link to law, theology, and prayer even more intriguing and, I believe, critical to its contemporary understanding and application in praxis.

This essay will proceed in three parts. First, I will consider the thought of philosopher Enrique Dussel, laying out two key contributions he makes toward affirming a basic right to protest through reflection on the 16th-century figure Bartolomé de Las Casas. Second, I will turn to a particularly Christian theological source in the work of Gustavo Gutiérrez. He speaks to the need to include and account for the experience of those who suffer in theological reflections on rights and Christian praxis. Third, I will return to the urgent need to reclaim and protect the right to protest as reflected in present-day American culture. To that end, I will argue that the right to protest articulates a right co-foundational with the rights to life, liberty, and property, and that this right is solidly grounded in a particularly Christian account of the dignity of the human person.

\section{Enrique Dussel: Crying Out and Negating Falsehoods}

Arising out of a context of silencing, exile, and protest himself, the Argentine/Mexican philosopher Enrique Dussel presents a critical perspective on Western modernity and suggests alternatives to its prevailing histories and theories that can be of great help to those wanting to subvert history and establish a fundamental right to protest. There are two key insights that I present in this Section. First, Dussel's anti-Cartesian meditations set the context for the rejection of the commonly accepted foundations for a history of modern rights while at the same time presenting the inspiration for the right to protest in his presentation of Bartolomé de Las Casas as the first critic of modernity. Second, Dussel's own political theory lays out principles and conditions upon which one might be able to recognize a "new" right to protest in contemporary rights discourse.

The turn to the subject, characteristic of modern philosophy, is often thought to have been ushered in with the "ego cogito" of René Descartes's Meditations. Dussel argues that this misses an earlier stage in modernity. Prior to Descartes, the so-called discovery of the so-called New World set the stage for Europeans to make a righteous claim for subduing indigenous persons and land best exemplified in the philosophical writings and arguments for conquest by Juan Ginés de Sepúlveda (Dussel 2014). ${ }^{4}$ However, as quickly as "ego conquiro" ("I conquer") was proclaimed, it met a response of "ego clamo" ("I cry out") by modernity's first critic: Bartolomé de Las Casas. Las Casas arrived in the "New World" as a landowner and slaver of indigenous people, but through encounters with Dominican friars who objected to his actions, he experienced a conversion and took up the cause of those he had formerly violated. Dussel imagines Las Casas, hearing the words of the Isaiah and the Gospel of John, "I am the voice in the desert crying out ... " (Is 40:3; Jn 1:23), and he asserts, "This is an accusative ego clamo, which criticizes the new established order; an I criticize in the presence of the ego conquiro that inaugurated Modernity" (Dussel 2014, p. 27). Dussel makes the connection between Las Casas and the Hebrew prophetic tradition, also embodied in John the Baptist, Jesus of Nazareth, as well as the Order of Preachers, which 
Las Casas joined. The prophet of the Lord castigates those who violate the Lord's justice, especially when forgetting one's own experience of freedom from bondage and taking advantage of the poor and vulnerable similar to the widow, the orphan, and the resident alien. Las Casas cried out in critical speech, or protest, for the sake of the Other he met in community living in the so-called New World, and he was motivated and able to refute claims of European superiority and a supposed "ius ad bellum" for the sake of defending prior natural rights (Ruston 2004)..$^{5}$ The false claim "ego conquiro" provoked the truthful claim "ego clamo."

Identifying the critique of modernity in Las Casas's "ego clamo," Dussel gained insight into the necessity of protest in response to the totalizing project of modernity. If the modern claim "I think" emerged out of "I conquer", then two consequences follow. First, there is no Other with which one can be in community; in order to emerge as thinking subject, the thinking subject had to "subject" the Other encountered to slavery or oblivion. Second, no one is left to make a counterclaim for rights against the subject in power. The modern subject is either caught in solipsistic meditation on himself/herself, or s/he has silenced, dominated, or destroyed the one who could make a rights claim on him/her. Dussel would echo this in his reflection on the ethical conscience as hearing the voice of the Other, writing: "On the contrary, not having ethical conscience means to have killed the Other, which is the same as saying that the Other keeps 'silent.' The 'silence' of the Other is nothing but the gag with which we have covered the Other's mouth. Nobody keeps 'silent'; it has been jealously kept under penalty of death" (Dussel 1973, p. 57, my translation). However, when one either forcibly or voluntarily experiences alienation, being made Other or even more mildly recognizing the cry of the Other, the an-Other is revealed to himself/herself, and the voice of the Other can be heard. Such an experience transforms a conscience, for

the prophet does not only hear the new word, but rather commits himself to the story so that the just word of the Other might be heard by all. The man with ethical conscience, upon hearing the voice-of-the-Other, is transformed, yet against his will, into a witness, a testimony from the Other (in Greek mártys: mártir): he represents, works as a delegate, bears witness for the sake of the oppressed Other before the Totality closed-as-totalitarian. (Dussel 1973, p. 59, my translation)

Only the experience of alienation can liberate a subject from himself-the subject finds himself only in the voice of the Other crying out in protest against Totality and demanding a witness. Due to its corruption, only in the negation of the negativity of modernity can the subject experience relationship and value beyond herself.

The negation of negation might seem a roundabout way to get at the necessary good that a subject wants to affirm. However, Dussel is not alone in recognizing the positivity of double negation. In a cross-disciplinary study, philosopher Wilfried Ver Eecke has explored the often surprising significance of saying "no" (Ver Eecke 1984). ${ }^{6}$ In developmental psychology, no saying has the effect of a child's self-identification through separation from her mother, opening up possibilities for explorations and judgments of her own needs and self-initiated relationships, such as that with her father. In Hegelian philosophy, negation is necessary for a movement beyond partiality toward a higher, more inclusive understanding of humanity that recognizes and affirms the Other as a subject. In linguistics, a "normal negation is characterized through a certain freedom and creativity of the speaker towards the content of the negation. This goes together with the intention to communicate a positive content to the other" (Ver Eecke 1984, p. 150). ${ }^{7}$ In acts of no saying, negation is an expression of the freedom of the subject, a liberation from constraints that prevent a truth in reality from becoming manifest within the subject and within relationships between the subject and others. Moreover, such speech acts call the subject in power to account for the presence, freedom, and power of the subject before him/her who just made that declaration. Dussel identifies this need for negation for the liberation of all parties involved. Only in the negation of the system of negation under which one is oppressed, in which one's voice is suppressed, does one come to an expansive affirmation of a history that 
is more inclusive both of the state of imprisonment and the state of liberation from that imprisonment (Dussel 1980, pp. 79-80). It also opens the horizon for a new community through communication. Only a right to protest can secure the ability to achieve that necessary liberation through negation. Dussel's political theory will remain cognizant of the need for this right and attend to the conditions for its realization and affirmation in political society.

Despite his anti-modern position, Dussel begins his treatise Twenty Theses on Politics not far from the archetypal modern political fathers Hobbes, Locke, and Rousseau in an account of the state of nature. In his account, however, the human being is not isolated, solitary, or individualistic; the human being is a herd animal, communal from his/her origin. Hearkening more to Aristotle than these moderns, he claims that human beings' first desire is a social will to live, in contrast to an individual will to power. From the perspective of Eurocentric modernity, power is domination, the negation of community in favor of the ego. However, out of the experience of postcolonial Latin America, Dussel demands a positive form of power through the will to live, the means by which persons together satisfy needs. He points out that, "[s]uch needs are negativities-hunger is the lack of food, thirst is the lack of drink, cold is the lack of heat, ignorance is the lack of cultural knowledge, etc.-which must be negated by the existence of basic goods (nourishment negates hunger: negation of a prior negation is an affirmation of human life)" (Dussel 2008, p. 14). Moreover, recognizing that if the will to live of each member were directed toward competing private interests, their potencies would annul each other resulting in common impotence. Instead, he points to the need for consensus: "an agreement by all participants—as free, autonomous, rational subjects with equal capacity for rhetorical intervention," where this is "therefore a 'communicative power' ..." (Dussel 2008, p. 15). ${ }^{8}$ This communicative power can be understood as a claim that human beings in the liberating political community have the subjective right to participate equally in discourse, through rhetorical language, in the determination of all other rights to basic goods. In a rejection of the individuality and pure negativity of the colonial experience of oppression, Dussel opens his vision for reformed politics in an affirmation of community and consensus through "commun-ication."

To advance his political theory, Dussel turns again to Las Casas for inspiration, using his forerunner's argument for the liberty of political subjects and recognition of rights inherent to them by nature. Las Casas wrote to the Spanish king regarding his potential subjects, "And their consent must be free, made of their own accord, since the decision affects them all and they cannot be deprived of something rightfully theirs by natural law, i.e., liberty. And some things have to be made clear to them prior to their choice, about tributes, about rights, about royal rents ..." (de Las Casas 1995, p. 253). Before determinations of objective rights or claims on goods can be made by an-Other, in this case, the king, Las Casas adverts to the respect for and security of the subjective right to free consent of the Amerindians, by virtue of the reason which they share with all human beings. Any transfer of potencies to authority is incumbent upon the authority's maintenance that the subjective right of a subject to transfer those potencies subsequently always remains potential, i.e., not active until consent is freely given. Dussel identifies this in the argument of Las Casas when he wrote:

The responsibility and obligation of 'preaching the Gospels' which the Roman pontiff has given to the Spanish kings grants them the 'right over the thing (jus in re),' but this right in potential comes into effect only via the consent of the Indians, by the free acceptance of such preaching. Without this consensus the right does not progress to the exercising of it in actu, as the 'right in relation to the thing (jus ad rem).' And as this consensus does not exist on the part of those affected, the conquest is illegitimate". (Dussel 2013, p. 184)

Political theories must attend to the due right of every constituent member to have her hearing before the public authority, and through that hearing, she can either offer or refuse consent for the authority's exercise of the trust for the subject's will to live. 
Where the consensus of all persons in a community has established democratic legitimacy, Dussel points out that all members continue to share solidarity in the legal sphere, meaning that each member has a responsibility for those who do not have recognized rights (Dussel 2008, p. 123). There is a problem, however, realizing this legal solidarity. Adjectives attached to rights such as "natural," "basic," "human," and "new" indicate that claims of the past are being challenged and discarded while new claimants to inherent liberties are petitioning for additions. This is a sign for Dussel that new rights, which initially existed only in the subjectivity of an oppressed or excluded people, have now, through protest and rebellion triumphed in discourse. Likewise, former rights, including many claimed to be natural under the strands of modernity's dominative logic under critique, might disappear as society moves through consensus toward liberation (Dussel 2008, p. 125). The necessary dynamism in historical movements can only be safeguarded by the very unrestricted democratic discourse that originally legitimated the government's authority.

Dussel notes that legal solidarity has a second problem. Over time the judicial function in government, meant to define norms and check the legislative and executive powers, became independent and isolated from the other two, leaving those functions to operate by taking justice into their own hands by creating laws and executing them without the due exercise of judicial prudence or the intervention of citizen power (Dussel 2008, p. 126). When this happens, governments can obstruct the liberating movement of a people through the diminution or abolition of rights that would threaten the execution of the government's self-made and self-reinforcing laws in its own drive for domination. For this reason, Dussel argues for the "right to truthful information" in the democratization of communication media and greater transparency and democratic participation in the judiciary, even by means of juries in all trials (Dussel 2008, pp. 130,134). Only when the voices of all persons are recognized and participate in open public discourse on the goods for their common living can true human liberation be advanced.

\section{Liberating One's Voice: Speaking the Truth in Protest with Christ}

The work of Enrique Dussel lays out a philosophical and political critique of modernity that attends to the experience of those excluded and oppressed by the dominating logic of a subjective turn without regard for the Other. Though his work is permeated by Christian elements, Dussel does not turn explicitly to the theological experience of those whose voices he seeks to include in philosophical and political discourse on rights. To ignore or silence that sphere of experience and subjective reflection in faith might be equally damaging to advancing the goal of liberation. Therefore, to advance Dussel's insights and fill this gap, I turn to theologies of liberation to ground the right to protest.

Theologies of liberation profess that there are not two destinies for humankind, one earthly and another other-worldly, "[r]ather there is only one human destiny, irreversibly assumed by Christ, the Lord of history. His redemptive work embraces all the dimensions of existence and brings them to their fullness. The history of salvation is the very heart of human history" (Gutiérrez 1988, p. 86). From a Christian perspective, Christ stands at the center of all histories as the source, norm, and end of our hope for liberation. Therefore, to understand the rights that affirm and secure that common destiny of all human beings, one must undertake critical reflection on the experience of Christ in faith, and that reflection must be done from the perspective of those most vulnerable and most in need of liberation-the oppressed, the marginal, those excluded from the incomplete prevailing histories prevalent in modernity. Achieving this critical conscience in the light of faith makes available to all the treasure of the voiced experience of those on the underside of history (Gutiérrez 1988, p. 102).

For the Church, Christ's story is the prime narrative and the referent of all histories. Due to his ignoble torture and state-sponsored murder, the history of those who suffer in particular was taken up by Christ on the cross, and his experience of suspension between those "above" and those "below" is illustrative for the response of the Church to suffering. In his book-length reflection $\mathrm{On}$ Job, Gutiérrez reflects on Jesus's experience of speaking 
the words of Psalm 22 from the cross (Gutiérrez 1987). ${ }^{10}$ Although the Gospel relates only the refrain of the psalm's opening lines, "My God, my God, why have you abandoned me?" (Mt 27:46; Mk 15:34), Jesus makes the whole rest of the song-a song that ends in trust in God's deliverance and praise of God's glory-his own. What is as important as the voiced expression of trust and praise in the attempt to silence Christ is the fact that, "Jesus did not compose this psalm, he inherited it ... But in adopting this psalm Jesus also gave expression to his hope in the liberating God who with predilection defends the poor and the dispossessed" (Gutiérrez 1987, p. 99). Jesus's cry from the cross is not his plea alone, but he takes up the cause of all those in history who have and will cry out in their suffering. In the crucified Christ, the suffering innocents find solidarity and are invited into his Body to share intimately in this communal life.

Christ's words from the cross, however, are more than a plea and praise. Gutiérrez says, "All these considerations do not eliminate the element of protest from the final words of Jesus; they are rather an attempt to situate it properly. Even in his lament Jesus 'spoke correctly of God.' His cry on the cross renders more audible and more penetrating the cries of all the Jobs, individual and collective, of human history" (Gutiérrez 1987, p. 101). The adoption of Psalm 22 is a transhistorical call to recognize in the voice of all who suffer innocently the negation of fallacious principles of domination, the rejection of systems of injustice that silence and exclude the vulnerable. The recognition of that call and reflection by those both at the center and on the periphery is notably the "second step" in the praxis of the Kingdom of God, or theology; a theology of liberation "is open-in the protest against trampled human dignity, in the struggle against the plunder of the vast majority of humankind, in liberating love, and in the building of a new, just comradely society-to the gift of the Kingdom of God" (Gutiérrez 1988, pp. 9, 12). When one speaks as Jesus did, negating falsehoods of domination and oppression, falsehoods that have been spread in theologies abiding in the totalizing project of modern history, one speaks truthfully and correctly of God and God's Kingdom in faith. Protest advances the testimony and praxis of truth.

Protest plays a preeminent role in the Christian experience of faith, both because it speaks the truth through negating the falsehood of sin and oppression and because it serves the affirmative testimony to the truth in human speech acts. The Gospel of Luke recalls the testimony of the early community of faith in Jesus and their joy in their encounter with Christ the liberator entering Jerusalem at the time of fulfillment. When those who would silence the voices of the crowd urged Jesus to rebuke his disciples, he refuses to concede to them their desire to maintain a status quo based on domination. The truth cannot be gagged. "'I tell you,' he replied, 'if they keep quiet, the stones will cry out'" (Lk 19:40). Not only humanity, but the whole of creation, formed in and sustained by the Word, has the power and right to testify to the truth. Truth is what justice intends and demands. To speak the truth is a duty, and the ability to carry out duty must be secured by right. For this reason, Gutiérrez wrote:

This cry cannot be muted. Those who suffer unjustly have a right to complain and protest. Their cry expresses both their bewilderment and their faith. It is not possible to do theology in Latin America without taking into account the situation of the most downtrodden of history; this means in turn that at some point the theologian must cry out, as Jesus did, "My God, my God, why hast thou forsaken me?" (Gutiérrez 1987, p. 101)

Theology, speaking about God, must be more than a plea and praise-it must include protest.

Additionally, Gutiérrez challenges the Church and all who speak about God to do so in truth, beginning with the witness of those whose voices have yet to be heard, those who suffer unjustly:

"That is why I cannot keep quiet: in my anguish of spirit I shall speak, in my bitterness of soul I shall complain" (Job 7:11). Nor can the poor and oppressed of Latin America remain silent ... What the poor and oppressed have to say may 
sound harsh and unpleasant to some. It is possible that they may be scandalized at hearing a frank avowal of the human and religious experience of the poor, and at seeing their clumsy attempts to relate their lives to the God in whom they have such deep faith. (Gutiérrez 1987, p. 101)

In the world, pervaded by sin and domination, the harsh words of protest and bitter complaint will scandalize and cause division. This is to be expected. Jesus, the Prince of Peace, is also the one who will bring fire and division (Lk 12:49ff). There is surely a danger in protest, struggle, and even revolt. Dom Hélder Câmara notes the threat of a spiral of violence, whereby systematic injustice as the first moment of violence attracts the second moment of violence in revolt and a third in repression and reprisals. For Câmara, however, the answer to violence cannot be violence, but it will require that "[ $t$ ]he privileged and the authorities will come to understand that common sense obliges one to choose between bloody and armed violence, on the one hand, and on the other the violence of the peaceful: liberating moral pressure" (Câmara 1971, p. 55). ${ }^{11}$ The widening horizon of such conflict and struggle, regardless, opens up new space for the voices of all to be heard and regarded. This irruption of the poor into the false peace of modernity can move the Church and the world toward a truer, lasting peace that is more than an unjust status quo cloaked in the absence of conflict.

Only through the experience of the suffering and attention to their protest can all Christians enter into authentic community and realize the vision of the Church as the Body of Christ. The Body of Christ is a wounded body, broken in the Eucharist, pierced on the cross, and crying out in protest to the heavens. It witnesses to the truth that is not yet realized but anticipated in the negation of that which is inhumane, divisive, and exclusionary. The cry of the poor and oppressed is a prophetic call to the world and an irruption into the historical account of modernity that is seated in the self. Gutiérrez's reflections on Job urge attentiveness to the voice of the protest in the suffering of the poor:

Only if we know how to be silent and involve ourselves in the suffering of the poor will we be able to speak out of their hope. Only if we take seriously the suffering of the innocent and live the mystery of the cross amid that suffering, but in the light of Easter, can we prevent our theology from being "windy arguments" (Job 16:3). But if we do, then we shall not deserve to hear from the poor the reproach that Job threw in the faces of his friends: "What sorry comforters you are!" (Job 16:2). (Gutiérrez 1987, p. 103)

This silence of modernity in the face of suffering is not to be symptomatic of quietism or apathy but must be genuine regard and attention that creates the space for communication and deeper solidarity. When a person who had dwelt in the modern perspective "from above" enters into dialogue and accepts an invitation to share the perspective "from below" by participating in the subversion of history, the communal "will to live", as Dussel puts it, empowers all.

This "will to live" might seem to be best supported in the most fundamental modern rights-life, liberty, and property, though this should be called into doubt. Many Christian theologies have sought to ground these rights in the tradition they inherited, and one doctrine that these theologies turn to most often is the belief that human beings are created to the image of God. In the Thomist tradition, out of which the Scholastics who taught both Las Casas and Descartes emerge, the "imago Dei" signifies: (1) a capacity for God, (2) selfmastery, and (3) dominion, or ownership (Ruston 2004, p. 112). Each of these signifiers seems to correspond roughly to the three fundamental rights enumerated and articulated by modern thinkers such as Locke and the American Founding Fathers. However, for Gutiérrez and Dussel, who have grounded their thought principally in the experience of Otherness in situations of negativity or suffering, the image of God must speak to something more. Gutiérrez points out that precisely because human beings were created in the image and likeness of God, they had to repudiate slavery and repression. He continues: "Humankind fulfills itself only by transforming nature and thus entering into relationships with other persons. Only in this way do persons come to a full consciousness of themselves 
as subjects of creative freedom which is realized in work. The exploitation and injustice implicit in poverty make work something servile and dehumanizing" (Gutiérrez 1988, p. 168). The image of God indeed corresponds to capacities and powers in human beings, which have been affirmed in modern subjective rights. However, Gutiérrez's insight on the potential for the dehumanization of those capacities in concrete experience requires an additional fundamental right to safeguard the other rights due to the image of God in each person. The right to protest repudiates the conditions for the negation of the image of God in human beings. It awakens masters to the relationships they would deny in their slaves and calls them to true relationships through which all, slave or master, can realize their capacities for God, self-mastery, and dominion. A secure right to protest in a society acknowledges the possible necessity of the irruption of prophetic voices through those oppressed, yet made to God's image and likeness, who can call for an accounting of justice. It keeps all human capacities and powers tentative and held in trust, being granted by the Other for the sake of the Other. Without a right to protest, however, the capacity for God can become idolatry—self-mastery, Other-mastery; and dominion, domination.

Grounding the dignity of the human person in an explicit and necessary relational understanding of the rights afforded in the image of God also can critique modern understandings of the subject that persist in Descartes's ego cogito as the decisive foundation of human subjectivity. Eleazar Fernandez has pointed out, "Not all individuals have the ability to reason (at least in the way we commonly construe reason), as in the case of total mental disability, but we all relate to the web of life. Descartes' human being, defined primarily in terms of thinking (Cogito ergo sum), must be transmuted into Cognatus ergo sum (I am related, therefore I am) and the Cognatus ergo summus (I relate, therefore we are)" (Fernandez 2004, p. 187). Fernandez has further noted that this understanding of human personhood has analogs in cultures beyond Latin America that have likewise suffered greatly due to modern imperialism but persist in hope of salvation and liberation in Christ through prophets such as Desmond Tutu and his "Ubuntu" theology. This theology has picked up the Xhosa proverb, "Ubuntu ungamntu ngabantu" ("I am because we are, and because we are I am") which echoes the insights presented here (Fernandez 2004, p. 206). Human identity and dignity are relational. The right to claim and even demand a relationship, therefore, is of the highest priority for all peoples.

\section{The Erosion of the First Amendment and the Urgency of a Right to Protest}

The context of my argument until now has been rooted in the scholarship of two men who communed with and wrote of the experience of those silenced through exclusion, oppression, and suffering, particularly in Latin America, drawing on sources from deep reflection within the contexts of their communities. This is not unique to the Latin American context alone, but across the Global South and in the very midst of the "developed" world, those on the margins remain silent or silenced. I contend that the root of this tragic reality lies in part within the often lauded and lionized modern philosophical foundations for the United States' enumeration of rights and privileges in its very Constitution. It might seem that the charter document of the United States, and the many constitutions which it inspired and influenced, already has secured the very right to protest for which I advocate. The First Amendment declares that "Congress shall make no law respecting an establishment of religion, or prohibiting the free exercise thereof; or abridging the freedom of speech, or of the press; or the right of the people peaceably to assemble, and to petition the Government for a redress of grievances" (The Constitution of the United States 1789). In the United States, the right to free speech, press, peaceful public assembly, and petition to the government for a redress of grievance itself seems secure and suggests the right to protest. This is the very allusion to which the Rev. Dr. Martin Luther King, Jr. made in his final speech act of protest before his assassination, declaring

But somewhere I read of the freedom of assembly. Somewhere I read (Yes) of the freedom of speech. (Yes) Somewhere I read (All right) of the freedom of press. (Yes) Somewhere I read (Yes) that the greatness of America is the right to 
protest for right. [Applause] And so just as I say we aren't going to let any dogs or water hoses turn us around, we aren't going to let any injunction turn us around. [Applause] We are going on. We need all of you. (King 1968)

As important as this call to account for legal systems is to really instantiate what is on paper for the fulfillment of right through a right to protest, the Latin American experience shows that the modern system of rights contains within it seeds of its own misuse and corruption. Reflecting from within the comfort of an educated, middle-class American background the cries and protest of the poor can evoke sympathy, but the urgency of the redress of those claims may be less easily felt. However, when one attends to and empathizes with the experience of oppressed persons in Latin America and engages in careful reflection on it, all persons, theologians such as myself included, can experience the liberation from ignorance of the dangers to fundamental rights if we do not first attend to a right to protest.

The modern theory contains the seeds of its own potential corruption, as Dussel points out in his critique of resultant forms of political authority and governance. Modern political theory innovated an understanding of civil authority that relies on principles identified earlier in this essay and which are widely accepted today, such as subjective right and popular consensus. The celebrated political philosopher John Locke wrote, "Whosoever, therefore, out of a state of Nature unite into a community, must be understood to give up all the power necessary to the ends for which they unite into society to the majority of the community, unless they expressly agreed in any number greater than the majority" (Locke 1986, p. 56). When an organized society is grounded not on sociality and recognition of the common will to live, as Dussel proposes, one ends up with proposals such as Locke's, where the state must be convincingly grounded on the subjective self-interest of individuals who would consent to exchange their own power to secure their goods of life for state provision of those goods. Government, in the abstract, takes on subjectivity as a representative of the will of the people to secure public goods. The subjective power of the state, however, unchecked and not confronted by an alterity in its domestic sphere can, if corrupt, pursue the will to power over those it promises to defend and serve.

As the powers necessary for the ends of the public good are transferred, there is little recourse to appeal the deprivation of rights by the state. On the one hand, the aggrieved can attempt to rescind their sanction of the state's monopoly on power and also affirm their identity in the face of oppression with "the subjective experience of collectively interrupting the sanctity of private property and police authority" (Case 2021). However, in the face of the overwhelming power of state police and military, there is little hope of bringing down the structures of injustice thus, except in a symbolic way. On the other hand, what really is left to the people as a last resort is an appeal to God's Providence. Locke wrote, "And where the body of the people, or of any single man, are deprived of their right, or are under the exercise of a power without right, having no appeal on earth they have a liberty to appeal to Heaven whenever they judge the cause of sufficient moment" (Locke 1986, p. 93). The aforementioned reflections on the theology of liberation affirm what even the early modern Locke reserves as the ultimate appeal to claim rights through an inalienable right to protest. The founders of the American republic were deeply influenced by Locke and established political measures to avoid the need for recourse to the ultimate appeal to heaven. However, many contemporary scholars are recognizing grave trends in contemporary American political governance that are picking away at the bulwark of those safeguards. If their concerns are not soon addressed, those in the United States and other countries with parallel constitutions may find themselves in need of that ultimate appeal in their struggle to reclaim the right to protest.

Nancy Chang's study of the creeping incursion of government restrictions on free speech attends to frightening precedents for silencing speech and dissent in the name of the public good. ${ }^{12}$ Calling attention to the judiciary's upholding of the Espionage Act of 1917 and Smith Act of 1940, up to and in the Patriot Act of 2002, she notes:

Confrontational protest activities, by their very nature, are acts that "appear to be intended ... to influence the policy of a government by intimidation or 
coercion." In addition, clashes between demonstrators and police officers and acts of civil disobedience - even those that do not result in injuries and are entirely nonviolent-could be construed as "dangerous to human life" and in "violation of the criminal laws." (Chang 2002, p. 45)

She places her hope in the judiciary itself as a check to runaway executive power and providing a generous interpretation of the Constitution which expands rights rather than constricts them in the name of the public good.

In light of the insights from Dussel and theologies of liberation, Chang's warning on the check of free speech in the name of the public good appears well founded. First, similar to Dussel, she notes that the isolation of the judiciary function of government from the legislative and executive complex has ceded way for the consolidation of the government's exercise of dominative power over the "consensus populi" from which they derive that authority. The restriction on the right to protest constitutes a betrayal of that trust that the government received to protect each citizen's standing and voice. Second, to name that the restriction is implemented in the name of checking activities that could be "dangerous to human life," perverts the richness of the understanding of living in the community through the exercise of manifesting in togetherness a negation of the negation. Likewise, from the experience of Christian liberation, witnessing to the Truth is a participation in the life of Christ, and this life is infinitely more liberating, even in death, than merely surviving in silence under worldly domination when one knows hope and joy. The right to protest in speech acts affirms the necessity of living in a community and communication with others therein even under threats to life and the supposed public good. The public good is to truly live with others, speak, and be recognized by the Other. Chang's contribution to American rights discourse highlights important applications of philosophies and theologies of liberation to the United States today.

There are, however, sincere voices that would argue for some limits on the right to speech for the public good understood properly as living with others. Steven Heyman notes that rights can make competing claims on members of society, and in most situations, public discourse must remain the arena for the common resolution of this confrontation due to the political character of any regulation that the government might entail (Heyman 2008). ${ }^{13}$ However, he points out:

Rights are rooted in respect for personhood. It follows that an individual cannot enjoy rights in relation to others unless they recognize him as a person. Recognition is the most fundamental right that individuals have, a right that lies at the basis of all other rights. At the same time mutual recognition is the bond that constitutes the political community. For these reasons, individuals have a duty to recognize one another as human beings and citizens. Hate speech violates this duty in a way that profoundly affects both targets themselves and society as a whole. (Heyman 2008, p. 171)

Reflecting on Heyman's insight in light of this paper, it should be clear that hate speech differs from protest in the content of the speech. Protest arises out of negation of falsehood for an ultimate affirmation of the truth; hate speech is not a negation of falsehood but a profession of falsehood by denying personhood and relationship. Hate speech refuses to listen to the experience of suffering. In fact, it inflicts suffering upon others in an attempt to gag and silence their voice, hearkening to Dussel's concern. The right to protest does not protect a right to injure. ${ }^{14}$ Hate speech does not engender true rights discourse; it attempts to silence the truth of the Other's personhood with deafening falsehood. Protest instead must be engendered by love speech, the just call for recognition and relationship with God and the Other, even in the face of suffering and death, as Christians find in the crucified Jesus.

\section{Conclusions}

Today the effects of the totalizing project of modernity are becoming clearer and clearer. At the same time, however, those dangerous manifestations have evoked provocative 
critiques of modernity, which are empowering those who have been excluded or silent in its historical account to rise up in protest. As Hélder Câmara said, "But we must be careful! Injustices are not the monopoly of the underdeveloped countries. They exist in the developed countries too ..." (Câmara 1971, p. 26). Therefore, from the ecclesial base communities in Latin America to the streets of the United States filled with those proclaiming that \#blacklivesmatter, we are hearing the voices of people once silenced. Philosophies and theologies of liberation, reflecting on their experience and amplifying their voices, can help advance their power in the truth, through the exercise of ethical conscience in the recognition of good by its absence in experiences of negative contrast. ${ }^{15}$ To support this effort, both Enrique Dussel and Gustavo Gutiérrez present accounts of recourse to what is arguably the most fundamental of all rights - the right of the human being to cry out in protest for recognition of her personhood by the Other. Furthermore, the Christian vision of the dignity of the human person created to the image of God provides an ultimate and universal ground for the right to protest. Protest essentially attends to the relationality of the oppressed calling out to the Other in truth. In protest, one finds communion with Christ, who stands with the most marginal and cries out with them to have the histories of all peoples heard and recognized with dignity. Christian ethics grounded in response to suffering makes both its speech and acts sacramental and prophetic. This prophetic work can create an improved discourse on rights between modernity and its critics. Consonant with the liberating vision of Dussel and Gutiérrez, one can hope that such inclusive discourse gives voice to the truth-a truth that sets all free.

Funding: This research received no external funding.

Institutional Review Board Statement: Not applicable.

Informed Consent Statement: Not applicable.

Data Availability Statement: Not applicable.

Conflicts of Interest: The author declares no conflict of interest.

\section{Notes}

1 J.P.M. Walsh makes an important contribution to an account of governance as mispat, "having the say," and tsedeq, "consensus," in the Hebrew Scriptures, or Old Testament of the Christian Bible, especially in the intro and chapter one of his book.

2 Some examples of those histories which either ignore or only speak about marginalized persons such as Amerindians and enslaved Africans without lifting their voices into histories and discourse include the influential, mid-20th century work Leo Strauss, Natural Right and History (Strauss 1953), and more recently, Dan Edelstein, On the Spirit of Rights (Edelstein 2018), as well as the theologically engaged essay by Brian Tierney, "Historical Roots of Modern Rights: Before Locke and After" (Tierney 2005).

3 I identify that I, the author, enter into this project from the position of a white, cisgender, non-Hispanic, educated, middle-class American academic researcher. There are inherent limitations and potential criticisms of the very addition of my voice out of a dominant political and cultural position to a discourse that continues to disregard or silence the voices of those most worthy and able to speak of the need for a right to protest. However, as will be shown in my interpretation and application of Dussel and Gutierrez, I work as a co-conspirator for the subversion of dominant narratives and invite interlocutors especially "from below" as a way to amplify their voices that I might step back and then let them "have the say."

4 In the first half of this paper, Dussel lays out a precise argument for the importance of turning to Descartes's educational influences to identify the historical context for the modern, use of philosophy to justify conquest, domination, and colonial empire in the name of humanitarian concerns and civilization.

5 Dussel and Ruston both highlight the extreme lengths taken by Las Casas in his arguments and his success in defending the Amerindians against claims to just war for violations against the natural law.

6 Ver Eecke dedicates chapters to no saying in each of the title disciplines to arrive at the conclusion that negation seeking a higher synthesis is necessary for the constructive constitution of the self. Although deeply embedded in Hegelian dialectic theory, the insights may be useful if subverted through explicitly anti-modern discourse.

$7 \quad$ Not only as subjects of developmental psychology, but very practically the voices of children in protest can guide the way to a more inclusive community and cross-generational creative action. Nicholas McMurry begins his essay “The Right for Protest to Be Heard" with a reflection on Article 12 of the UN Convention on the Rights of the Child. Noting that though children's voices have been subject to and often suppressed by adults, even within protest movements, recent breakthroughs from this marginalized and vulnerable subset of the global population have gained attention on many issues, but especially climate change, 
which disproportionately will affect them. Their calls for action have caught the attention of both the general public and that of states and international organizations considering what present actions to take in accord with the best interests of future generations (McMurry 2020).

8 Dussel goes into greater detail on the roots of popular consensus in the Roman and medieval, (pre-modern) legal tradition in the work of Bartolomé de Las Casas in his essay “Las Casas, Vitoria and Suárez, 1514-1617” (Dussel 2013, pp. 182-83).

9 It should be noted that Dussel's proposition of equal discourse upon rational grounds is neither a capitulation to the formalism of Habermasian discourse ethics nor a postmodern critique of reason altogether. Rather Dussel's anti-modernism is a rejection of the "violent, coercive, genocidal reason," though he "do[es] not deny the ration kernel of the universalist rationalism of the Enlightenment, only its irrational moment of sacrificial myth" (Dussel 1993, p. 75; Sørensen 2010). The use of "communication" here and throughout the rest of the essay draws attention to the centrality of community and participation in validating rational speech acts.

10 In this volume, Gutiérrez explores the question of how one is to talk about God from the perspective of the suffering innocent. He introduces two helpful notions to help: the language of prophecy and the language of contemplation. The effect of each of these types of discourse among human beings and God in God's self leads to the liberation of the voice of her who suffers and the world in which the suffering takes place.

11 Though Câmara's framework for the spiral of violence is powerful in its intuition and simplicity, it is difficult to parse when protest becomes "violent" and what effect violence and riot have on mobilization in nonviolent social movements. Recently, Benjamin Case challenged what he sees as a false dichotomy between violence and nonviolence, especially in what he calls "low-level violent actions," which have been shown to be significantly correlated to levels of nonviolent demonstrations and protest over time (Case 2021).

12 Following 9/11 and the passage of the Patriot Act, Chang's short book sponsored by the Center for Constitutional Rights charts what she identifies as a dangerous trajectory in American legal interpretation that endangers the civil liberties upon which the state was founded. A more thorough study of this same phenomenon is available in the well-researched and documented work by Ronald J. Krotoszynski, Jr. (Krotoszynski 2012).

13 Heyman's signal work applies a natural rights-based theory to many controversies over the interpretation of the First Amendment in the United States. He argues for strong protection of the rights to protest, even in rebellious speech acts such as flag burning and public demonstrations. However, he does at the end of his study concede that certain speech acts can and must be regulated, such as some forms of hate speech and pornography.

14 For a discussion of the history of American free speech considering the relationship between speech acts and injury suggested in the decision Chaplinsky v. New Hampshire (1942), see (Smolla 2009).

15 The 20th-century Belgian theologian Edward Schillebeeckx advanced a claim that there is "a very specific form of pre-religious experience [which serves] as the most basic experience of salvation accessible to all human beings: negative experiences of contrast. In radically negative situations, human persons spontaneously protest: 'No, it can't go on like this, we won't stand for it any longer' (God the Future of Man, 136). Although we have no consensus on what constitutes 'livable humanity' (the humanum), the indignation that arises when the human is violated is already an indication of an ethic that implicitly affirms a fuller future for humanity" (Hilkert and Schreiter 2002, p. 62).

\section{References}

Câmara, Hélder. 1971. Spiral of Violence. London: Sheed and Ward.

Case, Benjamin S. 2021. Molotov Cocktails to Mass Marches: Strategic Nonviolence, Symbolic Violence, and the Mobilizing Effect of Riots. Theory in Action 14: 18-38. [CrossRef]

Chang, Nancy. 2002. Silencing Political Dissent. Foreword by Howard Zinn. New York: Seven Stories Press.

de Las Casas, Bartolomé. 1995. Indian Freedom: The Cause of Bartolomé de Las Casas, 1484-1566, A Reader. Translated by SJ Francis Patrick Sullivan. Kansas City: Sheed \& Ward.

Dussel, Enrique. 1973. Para una Ética de la Liberación Latinoamericana II. Buenos Aires: Siglo XXI Argentina Editores.

Dussel, Enrique. 1980. Filosofía de la Liberación. Bogotá: Universidad Santo Tomás.

Dussel, Enrique. 1993. Eurocentrism and Modernity (Introduction to the Frankfurt Lectures). boundary 2, 20.3, The Postmodernism Debate in Latin America (Autumn 1993): 65-76. Available online: www.jstor.org/stable/303341 (accessed on 16 March 2021).

Dussel, Enrique. 2008. Twenty Theses on Politics. Translated by George Ciccariello-Maher. Durham: Duke UP.

Dussel, Enrique. 2013. Las Casas, Vitoria and Suárez, 1514-1617. In Human Rights from a Third World Perspective: Critique, History and International Law. Edited by José-Manuel Barreto. Newcastle upon Tyne: Cambridge Scholars Publishing, pp. $172-207$.

Dussel, Enrique. 2014. Anti-Cartesian Meditations: On the Origin of the Philosophical Anti-Discourse of Modernity. Journal for Cultural and Religious Theory 13: 11-53.

Edelstein, Dan. 2018. On the Spirit of Rights. Chicago: University of Chicago Press.

Fernandez, Eleazar S. 2004. Reimagining the Human: Theological Anthropology in Response to Systemic Evil. St. Louis: Chalice Press.

Gutiérrez, Gustavo. 1983. The Power of the Poor in History. Translated by Robert R. Barr. Maryknoll: Orbis Books. 
Gutiérrez, Gustavo. 1987. On Job: God-Talk and the Suffering of the Innocent. Translated by Matthew J. O'Connell. Maryknoll: Orbis Books.

Gutiérrez, Gustavo. 1988. A Theology of Liberation: History, Politics, and Salvation. Translated by Sister Caridad Inda, and John Eagleson. Maryknoll: Orbis Books.

Hannah-Jones, Nikole. 2019. Introduction, The 1619 Project. The New York Times Magazine, August 18. Available online: https: / / pulitzercenter.org/sites/default/files/full_issue_of_the_1619_project.pdf (accessed on 28 May 2021).

Heyman, Steven J. 2008. Free Speech and Human Dignity. New Haven: Yale UP.

Hilkert, Mary Catherine, and Robert Schreiter, eds. 2002. The Praxis of the Reign of God: An Introduction to the Theology of Edward Schillebeeckx, 2nd ed. New York: Fordham UP.

King, Martin Luther, Jr. 1968. I've Been to the Mountaintop," Address Delivered at Bishop Charles Mason Temple (3 April). Stanford University: The Martin Luther King, Jr. Research and Education Institute. Available online: https:/ / kinginstitute.stanford.edu/ king-papers/documents/ive-been-mountaintop-address-delivered-bishop-charles-mason-temple (accessed on 7 March 2021).

Krotoszynski, Ronald J., Jr. 2012. Reclaiming the Petition Clause: Seditious Libel, "Offensive" Protest, and the Right to Petition the Government for a Redress of Grievances. New Haven: Yale UP.

Locke, John. 1986. The Second Treatise on Civil Government. Amherst: Prometheus Books.

McMurry, Nicholas. 2020. The Right for Protest to Be Heard. Seton Hall Journal of Diplomacy and International Relations 21: 93-107.

Ruston, Roger. 2004. Human Rights and the Image of God. London: SCM Press.

Smolla, Rodney A. 2009. Words Which by Their Very Utterance Inflict Injury: The Evolving Treatment of Inherently Dangerous Speech in Free Speech Law and Theory. Pepperdine Law Review 36: 317-60.

Sørensen, Asger. 2010. Dussel's Critique of Discourse Ethics as Critique of Ideology. Public Reason 2: 84-101.

Strauss, Leo. 1953. Natural Right and History. Chicago: The University of Chicago Press.

The Constitution of the United States. 1789. Bill of Rights Transcript Text. National Archives. Available online: http://www.archives. gov / exhibits/charters/bill_of_rights_transcript.html (accessed on 7 March 2021).

Tierney, Brian. 2005. Historical Roots of Modern Rights: Before Locke and After. Ave Maria Law Review 3: $23-44$.

Ver Eecke, Wilfried. 1984. Saying "No": Its Meaning in Child Development, Psychoanalysis, Linguistics, and Hegel. Pittsburgh: Duquesne UP. Walsh, James P. M. 1987. The Mighty From Their Thrones: Power in the Biblical Tradition. Philadelphia: Fortress Press.

Zinn, Howard. 2003. The People's History of the United States. New York: Harper Perennial Modern Classics. 